Received: 09.07.2013.

Original research paper

UDK: 351.74.085-055.2(497.57=214.58)

\title{
THE DIFFERENCES IN PERCEPTION OF POLICE PROCEDURES BY THE ROMA AND LOCAL WOMEN ${ }^{1}$
}

Dr.sc. Mirjana Radetić - Paić,

Department of Educational Sciences

Juraj Dobrila University of Pula

Ronjgova 1. 52100 Pula

Republic of Croatia

e-mail:miradet@unipu.com

\section{SUMMARY}

As recent foreign researches show that the victims of extremistic delict need on average more time to recover from the assault, and that they are less satisfied with the treatment of the police than other victims, the aim of this paper is to find the answer to the question on how differently the women victims from the Roma minority group $(\mathrm{N}=80)$ percieve police procedures from local women $(\mathrm{N}=80)$, both living in Istria, Republic of Croatia.

The obtained indicators can confirm the set hypothesis. It can be concluded that there are differences in perception of police procedures by the Roma and local women, in the sense that the Roma women think that the police often exceed their authority, while local women, more often than the Roma ones, talk about some positive characteristics of police procedures and personal characteristics of police officers.

This research represents a step toward the role of female members of the Roma community from objects to subjects of criminal law and social security. The scientific and applicative value of this research's results are the guidelines which it gives for the creation and implementation of measures for the protection of families, women, children and youths belonging to the Roma minority group of the Istrian County, Republic of Croatia.

1 The author is published two thematically similar papers in the same journal:

Radetić-Paić, M. (2010): The Roma and Other Istrian Residents' Opinions about Some Aspects of the Level of Information of the Public by the Police in the Context of Education and Ethnic Discrimination. Metodički obzori, 5, 9; 19-30.

Radetić-Paić, M. Opašić, V. i Kostešić, I. (2012): Police procedure as a possible indicator of institutional extremism. Metodički obzori, 7, 3(16); 25-36. 
Keywords: extremism, police procedure, the Roma women

\section{INTRODUCTION}

The citizens of any local community have the need and right for safety and protection. If they do not feel protected and safe their commitment to cooperate with the police will not take place. This problem is emphasized with members of minorities and other vulnerable groups, especially the Roma, which is usually one of the main reasons of their not taking part into community initiatives.

The authors Cajner Mraović and Mraović (2000, 2003) emphasize that the experience of victimization by extremistic violence, and especially the reaction of the community on such experience of an individual seriously affects the way in which the members of some ethnic, racial, religious or any other groups victim of violence think feel and act in the social community. This phenomenon affects the choice of their living place, working place and the place for spending their free time and moving around. The members of such, usually minority groups, are afraid of assoults on their life and body, and they are not satisfied with the protection offered by the community. This is the reason why they often organize themselves, which usually represents the beginning of new violence.

The role of the police in the community, and also in the local one, is a very popular theme. In their traditional way of functioning, the main role of the police is to control crime. The other key functions of the police are offering urgency services, keeping order and peace on streets and other public places and offering to citizens a large spectrum of services which do not have an urgent character (Rosenbaum, 1998).

What the citizens of a certain local community percieve, and what is "offered" by different mass medias, is a picture of police officers as "the fighters against crime" or the protectors of the community from violence and anarchy.

Contrary to that, the picture of police officers as the ones who give services which are not linked to crime remains unclear and not fully completed (Punch, 1979). Reiner (1994) even thinks that such a picture is not even percieved by the widest number of people. Even when we are conscious of the fact that offering services to citizens and care for them are also police duties, it is still difficult to percieve them as the main reason for the existence and organisation of the police as a social institution. It is very important to add here that it is not only a question of the public (or laymen) perception, but that the mere police officers tend to have these conceptions and that they will explain their role in the social community in terms of control, not care (Stephens and Saul, 1994).

According to Westley (2004), police violence is at the same time a prerogative, a profession and a duty in some countries. The police own the power which includes the use of violence because in the civil society they have the monopoly of legal means of violence owned by the state. The duty of the police is, in a way, to use violence as a control measure or as prevention of possible disruption of order. Imprisonment and penalizing the offenders is the main duty of the police. At the same time they are 
under constant pressure and criticism of the public and under the constant thinking about arresting (with the problem of lack of evidence) and public opinion which forces them to take action. The author says that such a dilemma is solved in the United States of America by illegal use of violence and exceeding of police authority.

The author (Westley, 2004) also gives research results according to which 37 percent of examinees from the sample examined which had 50 percent of examinees from the police station, believe in the justification of the use of violence with the aim of imposing respect toward the police. It is also emphasized that a police officer will not use sanctions against his or her colleagues who exceed their authority by using violence. In this sense, collective sanctions because of violence use let those who tend to use it to do it without fear. It still must not be forgotten that each police officer is conscious of the danger linked to the illegal use of violence and uses it to a certain extent, always finding justification for exceeding his or her authority by saying, for example, that the person offered resistance while being arrested.

Westley (2004) concludes that the police act in a certain way to gain respect, especially by minority groups. Franklin (2000; by Cajner Mraović \& Mraović, 2000) is of a similar opinion. The results of his researches show that committers of extremistic delicts percieve their violent behaviour as positive, thinking that the society approves the violence they commit over different minority groups of citizens.

Literature (Uzelac, 2004b) states that professionals should not be making mistakes in judging who goes away from the standard behaviour and how, which is determined by a wide range of behaviours and is damaging for the individual and (or) for his environment. It also asks if all mentioned requires an additional professional help, even more since the powerful lever of authority is and remains in their hands by which they take as their right to use force. It all raises the question of ethics. Uzelac (2004b) concludes that the starting point in judging others' behaviour as ethical or not, which comes out of one's personal ethical frames, is unquestionably critical.

Uzelac (2004a) reflects if ethical values, as the sources of judgement, can be of help. The other question is how much are these questions permeated in all principles (including the ethical ones) on which the professional intervention rests. The example of some professions (medical) which have defined these principles in a more detailed way is set. In them there is a list of positive and negative moral and psychological characteristics of a professional. The positive or desirable characteristics are humanity, responsibility, altruism, honesty, justice, consistency, sincerity, self-criticism, modesty and so on. The negative or undesirable ones are egoism, vanity, arrogancy, jealousy, and so on. These characteristics are one of the preconditions of a professional's right judgement about another person's behaviour or about applying some regulatory measures.

Bowling (1999) analyses the police priorities and comes to the conclusion that the police ranks some forms of crime and harassment (like sexual assaults and different way of torturing the victims) as priorities for intervention. Racial assaults are on the third place when they are related to Asian ethnic minorities (behind burglary and robbery), on the fourth place for women and on the sixth for men of Afro-American 
origins, and on the seventh for local citizens. In spite of some differences in views of some ethnic groups and local citizens, the local ones think that racial assaults on ethnic minorities are one of the three most important police priorities. The indicators which show that local citizens consider racial assaults on local minorities as a problem (32 percent) an that their solution should be a priority (14 percent), show that there is a kind of care or paying attention to racially based assaults by the local citizens.

The problem of institutional extremism must be mentioned here. The authors Cajner Mraović and Mraović (2000) emphasize that institutional extremism affects the routine reaction, the dealing with extremistic delicts and the way in which the members of some, especially minority groups, will be treated as victims, but also as workers, witnesses, suspects and citizens. Institutional extremism is a process by which the members of some ethnic, religious or other groups are systematically discriminated and disrespected by individuals working in certain institutions, and there is the possibility for these institutions to be bearers of different kinds of dicrimination. This problem is even more important if known that the practice which leads to extremistic outcomes is not something happening without the knowledge of those who practise it, but they fail to consider the consequences of such actions for members of ethnic minorities.

On the other hand, the marginalisation and discrimination of the Roma, especially women, can be analysed in the context of the local community as well as the Roma minority group.

During 2002 The National Department for the Protection of Family, Motherhood and the Youth conducted a research under the name of Structure of the Roma Family and the Conception of Parenthood in them. Eight hundred parents of the Roma community in the Republic of Croatia were questioned (The National Department for the Protection of Family, Motherhood and the Youth, 2002). The results obtained showed that the main decisions in the Roma families were made by men or husbands, while the traditional "women" duties (food preparation, housecleaning, shopping) and children care were left to women (90 percent of women take care of the household, 74.1 percent of them take care of children on their own). The total number of parents questioned think that 11 percent of girls and six percent of boys should get married before being 18 years old.

The Roma women are usually so marginalized, a high level of fertility and a traditional division of roles in the family is present. The relation towards women is not emancipated. They are prone to discrimination which influence in the raising of children and functioning of the family. Ten to twelve year-olds, and even younger children, take part in their parents' or family jobs which makes their regular education difficult.

An important characteristic of the Roma family is that it is mostly young. According to the 1998 results by the Institute for Social Sciencies Ivo Pilar, the members of 50 percent of questioned households were under 39 years of age, while households with older members were very rare (The Institute for Social Sciences Ivo Pilar, 1998). In the life of the Roma, including their women, customs have a special place. They 
have been kept alive in their identical, original form till today. Unfortunately, some of them are contrary to the regulations of the area they live in, like marriage arrangement between fathers of the future spouses, with a rich compensation to the bride's (who is usually under age) father.

The Republic of Croatia is a signatory country of The Convention on the Elimination of all Forms of Discrimination against Women brought by The General Assembly of the UN in 1979 (UN General Assembly, 1979). It is the first all inclusive internationally accepted document about women rights. In its Article 1, this Convention gives the definition of discrimination of women: "For the purposes of this convention the discrimination of women represents any difference, exclusion or limitation in terms of gender, the consequence or purpose of which is to endanger or make impossible the affirmation, realisation or performing of human rights and personal freedoms in the political, economic, social, cultural, civil or other area despite of their merital state and based on the equality between men and women."

Finding the position of the Roma family more difficult than tose of other minority communities in Europe, The European Council and The European Union (Zidarić, 1994) have recently (and especially from 1993) given special attention to the Roma issue, stimulating their members and other countries in the region to systematically solve these problems so to overcome as quickly as possible the gap found and to improve the Roma life conditions. At the same time they ask in their resolutions and advice for a multydisciplinary and systematic approach in solving the problems in all areas, especially children rights, education, health and social care, adequate dwelling and eradication of discrimination and segregation of any kind (racial, national, religious, sexual,...).

In 2003 the Croatian Government brought „The National Programme for the Roma“ (The Croatian Government, 2003) and the complementary „Action Plan of the Decade of the Roma Implementation, 2005-2015“ (The Croatian Government, 2005). The Republic of Croatia guarantees, among others, the equality for members of all national minorities. Freedom, equality, national and gender equality, social and human rights are among the highest values of its Constitution (Articles 1 and 15) (The Committee on the Constitution, Standing Orders and Political System of the Croatian Parliament, 2001). Article 14 of the Croatian Constitution guarantees "rights and freedoms to any individual in the Republic of Croatia, regardless their race, colour of the skin, gender, language, religion, political or other conviction, national or social origin, property, birth, education, social status or other characteristic. Everyone is equal in front of the law."

When women are victimised in some way, the problem of finding out such a crime is present. The victims of extremistic delicts are less ready to report to the police about their victimisation than other victims. Such victims can often identify the committer, but the fact that they know him or her generates their resistance toward reporting the crime. The reasons for that lie in traumas caused by victimisation, but there is another important reason for not reporting the delicts, and this is the fear of the committer's revenge or of the possibility to become victims again (Cajner Mraović 
and Mraović, 2000).

Schwendinger and Schwendinger (1983) concluded that although laws made a "distinction" between people of different skin colours, it is disturbingly evident in practice that an Afro-American will not be approached in the same way by the law system, or they will not be given the same treatment as Afro-American local women.

Hawkins (1987; by O'Brien, 1989) concludes that Afro-American women victims are generally not treated in a proper way, and especially if the committer is a person of the same origins. Afro-American women think that they will not be righteously treated by the police if they report rape. Wyatt's research (1992) shows that these women will not reveal their victimisation until at least a year from the happening passes. They will also report less this kind of crime (McKean, 1994).

It can be concluded, based on everything formerly mentioned, that minority members usually do not want to report delicts by which they are victimised because they are afraid that the law system is not on their side. This makes such and similar researches justified. On the other hand, the position of women inside the minority community is traditionally marginalised. In this sense, lack of confidence is usually shown toward the police to which the crimes are reported.

\section{THE AIM OF THE RESEARCH AND HYPOTHESIS}

This research comes out not only from the traditional criminology which deals with committers and victims of delicts, but takes into account also modern criminological models, especially the theory of social control which demands for dealing with those who create and execute laws. As recent researches (Miethe et al.,1987; Bowling, 1999; Ogawa, 1988, 1999; Bowling, 1999; Levin, 2002; Zoon, 2002; Ren et al., 2005; Correia, 2010; Jang et al., 2010) show that the victims of extremistic delict need on average more time to recover from the assault, and that they are less satisfied with the treatment of the police than other victims, the aim of this paper is to find the answer to the question on how differently the women victims from the Roma minority group percieve police procedures from local women, both living in Istria, the Republic of Croatia.

In the research it is generally assumed that the women from the Roma minority group, who are discriminated in many ways from local women, will subjectively percieve police procedures.

Along with that, a hypothesis has been set,which assumes the existance of differences in percieving police procedures by the Roma and local women from Istria, the Republic of Croatia. 


\section{METHODS}

\section{Sample of examinees}

The sample of women examinees is casual. The sample of female members of the Roma minority group $(\mathrm{N}=80)$ from Istria, the Republic of Croatia, is chosen from the evidence of the Social Care Centres from the Istrian County, the republic of Croatia (The Social care centres of Pula, Buje, Rovinj, Poreč, Pazin and Labin). The reason for that is that these centres still have the most complete data about the members of the observed national minority, and the assumption exists that a large number of their members enjoy the social rights (Radetić-Paić, 2009). The author Šućur (2005) confirms the fact that social help is the most usual income to the Roma, or that in almost three fourths of households it is the first or second source of income. The group of female examinees belonging to the local community of the Istrian county, the Republic of Croatia $(\mathrm{N}=80)$ is equalised according to age and education to the Roma women, and it is also mostly chosen from the evidences of the centres mentioned, since it is, along with other characteristics, very similar to the Roma group in socio-economical conditions (enjoying some kind of material protection). The sample of local women has also been chosen from the evidence of the Central Employment Office to a lower extent. Attention has to be payed to interpretation of facts since the facts do not need to be representative for the population of the Roma and local women to the whole.

\section{Sample of variables}

The questionnaire has been made in cooperation with the Study group for planning, implementation and monitoring of the "Police in the community" Strategy, the Study group for planning, implementation and monitoring of the project Organization of municipal prevention and the OESS mission in Croatia. In this research, a group of 21 variables concerning the perception of police procedures in the area of living has been used. Tese variables are as follows:

- Efficacity of the police in crime prevention

- The use and help of the police which citizens have

- The help which the police gives to victims of crime

- Tidiness of police officers

- Honesty of police officers

- Politeness of police officers

- Reliability of police officers

- Professionality of police officers

- Promptness of police officers

- Kindness of police officers

- Resolution of police officers 
- Motivation of police officers

- Responsibility of police officers

- Approachability of police officers

- Consistency of police officers

- Efficacity of the police in the protection of women against violence

- Efficacity of the police in the protection of children against violence

- Efficacity of the police in the protection of minority groups against violence

- Efficacity of the police in keeping public order

- Efficacity of the police in fighting juvenile delinquency

- Do you think that the police often exceeds their authority?

\section{Methods of data interpretation}

Along with the working out of marginal frequencies on all observed variables, the discriminatory analysis as a multivariant method has been used. The discriminatory analysis which was used is a part of the SPSS for Windows software.

\section{Conduction of the research}

The research was carried out in 2004 and 2005. In cooperation with The Roma Association of the Istrian County and the Social Care Centres from Pula, Buje, Rovinj, Poreč, Pazin and Labin, each examinee filled in the questionnaire which became part of the sample according to the instructions for questionnaire filling. They had to answer in a scale. Examinees were told that the questionnaires were anonymous. 


\section{RESULTS AND DISCUSSION}

\section{Questionning of differences in perception of police procedures by the Roma and local women based on descriptive indicators}

Table 1. Marginal frequencies of variables by which the perception of police procedures in the area of living has been described (the main differences between the two groups)

\begin{tabular}{|c|c|c|c|c|c|c|c|}
\hline \multirow{3}{*}{ Variable } & \multirow{3}{*}{ Chategory } & \multicolumn{2}{|c|}{ All } & \multicolumn{2}{|c|}{ The Roma women } & \multicolumn{2}{|c|}{ The local women } \\
\hline & & ap. & $\%$ & ap. & $\%$ & ap. & $\%$ \\
\hline & & 160 & 100 & 80 & 100 & 80 & 100 \\
\hline \multirow{4}{*}{$\begin{array}{l}\text { Efficacity of the police in } \\
\text { crime prevention }\end{array}$} & very good & 5 & 3,1 & 3 & 3,8 & 2 & 2,5 \\
\hline & good & 72 & 45 & 29 & 36,3 & 43 & 53,8 \\
\hline & bad & 62 & 38,8 & 34 & 42,5 & 28 & 35 \\
\hline & very bad & 21 & 13,1 & 14 & 17,5 & 7 & 8,8 \\
\hline \multirow{4}{*}{$\begin{array}{l}\text { The use and help of the } \\
\text { police which citizens } \\
\text { have }\end{array}$} & verygood & 6 & 3,8 & 2 & 2,5 & 4 & 5 \\
\hline & good & 84 & 52,5 & 37 & 46,3 & 47 & 58,8 \\
\hline & bad & 51 & 31,9 & 27 & 33,8 & 24 & 30 \\
\hline & verybad & 19 & 11,9 & 14 & 17,5 & 5 & 6,3 \\
\hline \multirow{4}{*}{$\begin{array}{l}\text { The help which the police } \\
\text { gives to victims of crime }\end{array}$} & very good & 6 & 3,8 & 4 & 5 & 2 & 2,5 \\
\hline & good & 74 & 46,3 & 32 & 40 & 42 & 52,5 \\
\hline & bad & 61 & 38,1 & 36 & 45 & 25 & 31,3 \\
\hline & very bad & 19 & 11,9 & 8 & 10 & 11 & 13,8 \\
\hline \multirow{4}{*}{$\begin{array}{l}\text { Motivation of police of- } \\
\text { ficers }\end{array}$} & very good & 5 & 3,1 & 2 & 2,5 & 3 & 3,8 \\
\hline & good & 93 & 58,1 & 40 & 50 & 53 & 66,3 \\
\hline & bad & 48 & 30 & 28 & 35 & 20 & 25 \\
\hline & very bad & 14 & 8,8 & 10 & 12,5 & 4 & 5 \\
\hline \multirow{4}{*}{$\begin{array}{l}\text { Consistency of police of- } \\
\text { ficers }\end{array}$} & very good & 4 & 2,5 & 1 & 1,3 & 3 & 3,8 \\
\hline & good & 98 & 61,3 & 44 & 55 & 54 & 67,5 \\
\hline & bad & 48 & 30 & 27 & 33,8 & 21 & 26,3 \\
\hline & very bad & 10 & 6,3 & 8 & 10 & 2 & 2,5 \\
\hline \multirow{4}{*}{$\begin{array}{l}\text { Efficacity of the police in } \\
\text { the protection of women } \\
\text { against violence }\end{array}$} & very good & 6 & 3,8 & 5 & 6,3 & 1 & 1,3 \\
\hline & good & 75 & 46,9 & 31 & 38,8 & 44 & 55 \\
\hline & bad & 60 & 37,5 & 31 & 38,8 & 29 & 36,3 \\
\hline & very bad & 19 & 11,9 & 13 & 16,3 & 6 & 7,5 \\
\hline \multirow{4}{*}{$\begin{array}{l}\text { Efficacity of the police } \\
\text { in the protection of } \\
\text { minority groups against } \\
\text { violence }\end{array}$} & very good & 10 & 6,3 & 6 & 7,5 & 4 & 5 \\
\hline & good & 75 & 46,9 & 28 & 35 & 47 & 58,8 \\
\hline & bad & 56 & 35 & 29 & 36,3 & 27 & 33,8 \\
\hline & very bad & 19 & 11,9 & 17 & 21,3 & 2 & 2,5 \\
\hline \multirow{4}{*}{$\begin{array}{l}\text { Efficacity of the police in } \\
\text { fighting juvenile delin- } \\
\text { quency }\end{array}$} & very good & 5 & 3,1 & 4 & 5 & 1 & 1,3 \\
\hline & good & 80 & 50 & 36 & 45 & 44 & 55 \\
\hline & bad & 58 & 36,3 & 30 & 37,5 & 28 & 35 \\
\hline & very bad & 17 & 10,6 & 10 & 12,5 & 7 & 8,8 \\
\hline \multirow{4}{*}{$\begin{array}{l}\text { Do you think that the } \\
\text { police often exceeds their } \\
\text { authority? }\end{array}$} & absolutely yes & 14 & 8,8 & 11 & 13,8 & 3 & 3,8 \\
\hline & probably yes & 64 & 40 & 34 & 42,5 & 30 & 37,5 \\
\hline & probably no & 69 & 43,1 & 30 & 37,5 & 39 & 48,8 \\
\hline & absolutely no & 13 & 8,1 & 5 & 6,3 & 8 & 10 \\
\hline
\end{tabular}


The group of answers related to the perception of police procedures in the area of living of the two groups of examinees generally shows, thanks to the descriptive analysis, that the Roma women badly percieve the efficacity, procedures and personal characteristics of police officers. The differences between the two groups (Table 1) are larger on the variables of efficacity of the police in crime prevention, the use and help which the citizens have from the police, the help which the police gives to victims of crimes, the motivation and consistency of police officers, the efficacity of the police in protecting women and minority groups from violence, the efficacity of the police in fighting juvenile delinquency, and the police exceeding their authority. In more than 50 percent of cases the Roma examinees estimate these characteristics as "bad" and "very bad," or that they "absolutely" and "probably" think that the police often exceed their authority.

\section{DISCRIMINATORY AND UNIVARIATE ANALYSIS OF VARIABLES' VARIANTS WHICH DESCRIBE THE PERCEPTION OF POLICE PROCEDURES BY THE ROMA AND LOCAL WOMEN}

The discriminatory and univariate analysis of variants tried to estabilish the latent level of differences between examinees or, in other words, the existance and sort of differences between the two groups of female examinees. The discriminatory analisys between the two groups of examinees - the Roma and local women - isolated a theoretically possible discriminatory function in the group of variables which describe various ways of police procedures in the area of living. This discriminatory function is statistically important on the level $\mathrm{p}=0.01$ (Table 2) and it discriminates well the two groups of examinees so the set hypothesis by which it is assumed that there are differences in perception of police procedures by the Roma and local women can be confirmed.

Table 2. Eigenvalues and Wilks' Lambda

\begin{tabular}{|c|c|c|c|c|}
\hline Eigenvalues & & & & \\
\hline Function & Eigenvalue & $\%$ of Variance & Cumulative \% & $\begin{array}{l}\text { Canonical } \\
\text { Correlation }\end{array}$ \\
\hline & 278 & 100,0 & 100,0 & ,467 \\
\hline Wilks' Lambda & & & & \\
\hline $\begin{array}{l}\text { Test of Func- } \\
\operatorname{tion}(\mathrm{s})\end{array}$ & $\begin{array}{l}\text { Wilks' } \\
\text { Lambda }\end{array}$ & Chi-square & df & Sig. \\
\hline 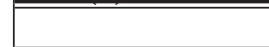 & $1 \quad, 782$ & 36,225 & 21 & 0,000 \\
\hline
\end{tabular}

If the discriminatory coefficients of this discriminatory functions (Table 3) are observed it can be noticed that it mostly consists of variables which describe the politeness of police officers, efficacity of the police in fighting juvenile delinquency and the exceeding of authority by the police. The use and help which citizens have from the police, the efficacity of the police in protecting minorities, the consistency, promptness and motivation of police officers are seen as negative. The variables which mostly correlate with the discriminatory 
function are those describing the efficacity of the police in protecting minorities, consistency and motivation of police officers, the use and help which citizens have from the police, and exceeding of authority by the police. All are negatively seen.

Table 3. Standardized Canonical Discriminant Function Coefficients (C) and Structure Matrix (S)

\begin{tabular}{|l|r|r|}
\hline Variable & \multicolumn{1}{|c|}{$C$} & \multicolumn{1}{|c|}{$S$} \\
\hline \hline Efficacity of the police in crime prevention &,- 064 &,- 304 \\
\hline The use and help of the police which citizens have &,- 714 &,- 370 \\
\hline The help which the police gives to victims of crime &, 283 &,- 048 \\
\hline Tidiness of police officers &,- 004 &, 000 \\
\hline Honesty of police officers &, 369 &,- 167 \\
\hline Politeness of police officers &, 699 &, 145 \\
\hline Reliability of police officers &,- 197 &,- 185 \\
\hline Professionality of police officers &, 084 &,- 103 \\
\hline Promptness of police officers &,- 394 &,- 204 \\
\hline Kindness of police officers &,- 098 &,- 189 \\
\hline Resolution of police officers &, 231 &,- 050 \\
\hline Motivation of police officers &,- 359 &,- 364 \\
\hline Responsibility of police officers &, 268 &,- 219 \\
\hline Approachability of police officers &, 293 &,- 187 \\
\hline Consistency of police officers &,- 465 &,- 375 \\
\hline $\begin{array}{l}\text { Efficacity of the police in the protection of women } \\
\text { violence }\end{array}$ &,- 016 &,- 191 \\
\hline Efficacity of the police in the protection of children against violence &, 279 &,- 168 \\
\hline Efficacity of the police in the protection of minority groups against violence &,- 640 &,- 468 \\
\hline Efficacity of the police in keeping public order &,- 162 &,- 211 \\
\hline Efficacity of the police in fighting juvenile delinquency &, 599 &,- 082 \\
\hline Do you think that the police often exceeds their authority? &, 393 &, 362 \\
\hline
\end{tabular}

Based on the insight of discriminatory coeficients of the function, the structure of the matrix and the position of centroids (Table 4) it can be concluded that the Roma women, differently from the local ones, think that the police often exceed their authority.

Table 4. Functions at Group Centroids

\begin{tabular}{|l||c|}
\hline & Function \\
\hline \hline The Roma women &,- 524 \\
\hline The local women &, 524 \\
\hline
\end{tabular}

The obtained results also show that local women percieve the use and help which citizens have from the police, efficacity of the police in protection of minorities, consistency, promptness and motivation of police officers statistically more often than the Roma ones. 
Table 5.The results of the univariat analysis of variants in original values

\begin{tabular}{|c|c|c|c|c|c|c|}
\hline \multirow[b]{2}{*}{ Variable } & \multicolumn{2}{|c|}{ Mean } & \multicolumn{2}{|c|}{ Std. Deviation } & \multirow[t]{2}{*}{$\mathbf{F}$} & \multirow{2}{*}{$\begin{array}{c}P \\
\text { (Sig.) }\end{array}$} \\
\hline & $\begin{array}{c}\text { The } \\
\text { Roma } \\
\text { women } \\
\end{array}$ & $\begin{array}{l}\text { The } \\
\text { local } \\
\text { women }\end{array}$ & $\begin{array}{c}\text { The } \\
\text { Roma } \\
\text { women }\end{array}$ & $\begin{array}{c}\text { The } \\
\text { local } \\
\text { women } \\
\end{array}$ & & \\
\hline $\begin{array}{l}\text { Efficacity of the police in crime } \\
\text { prevention }\end{array}$ & 2,74 & 2,50 & ,79 & ,69 & 4,075 &, $045^{\star}$ \\
\hline $\begin{array}{l}\text { The use and help of the police } \\
\text { which citizens have }\end{array}$ & 2,66 & 2,38 & ,79 & ,68 & 6,030 &, $015^{\star}$ \\
\hline $\begin{array}{l}\text { The help which the police gives } \\
\text { to victims of crime }\end{array}$ & 2,60 & 2,56 & ,74 & ,76 & , 100 & ,752 \\
\hline Tidiness of police officers & 2,13 & 2,13 & 77 & ,51 & ,000 & 1,000 \\
\hline Honesty of police officers & 2,39 & 2,28 & ,72 &, 55 & 1,232 &, 269 \\
\hline Politeness of police officers & 2,14 & 2,24 & ,71 & ,60 & ,930 & ,336 \\
\hline Reliability of police officers & 2,46 & 2,33 &, 81 &, 59 & 1,504 &, 222 \\
\hline Professionality of police officers & 2,38 & 2,30 &, 75 &, 62 & ,471 & ,494 \\
\hline Promptness of police officers & 2,61 & 2,45 & ,80 & ,71 & 1,838 & ,177 \\
\hline Kindness of police officers & 2,36 & 2,24 &, 70 &, 56 & 1,568 & 212 \\
\hline Resolution of police officers & 2,29 & 2,25 & ,73 & ,68 &, 112 & ,738 \\
\hline Motivation of police officers & 2,58 & 2,31 &, 74 & ,63 & 5,827 &, $017^{\star}$ \\
\hline Responsibility of police officers & 2,36 & 2,23 & ,66 &, 53 & 2,117 &, 148 \\
\hline Approachability of police officers & 2,49 & 2,36 & ,66 & ,62 & 1,532 & 218 \\
\hline Consistency of police officers & 2,53 & 2,28 & ,69 &, 57 & 6,182 & ,014 \\
\hline $\begin{array}{l}\text { Efficacity of the police in the } \\
\text { protection of women against } \\
\text { violence }\end{array}$ & 2,65 & 2,50 & ,83 & ,66 & 1,612 & ,206 \\
\hline $\begin{array}{l}\text { Efficacity of the police in the } \\
\text { protection of children against } \\
\text { violence }\end{array}$ & 2,66 & 2,53 &, 87 & ,67 & 1,247 & 266 \\
\hline $\begin{array}{l}\text { Efficacity of the police in the } \\
\text { protection of minority groups } \\
\text { against violence }\end{array}$ & 2,71 & 2,34 & ,89 & ,62 & 9,632 &, $002^{\star *}$ \\
\hline $\begin{array}{l}\text { Efficacity of the police in keeping } \\
\text { public order }\end{array}$ & 2,38 & 2,23 & ,77 & ,57 & 1,956 & ,164 \\
\hline $\begin{array}{l}\text { Efficacity of the police in fighting } \\
\text { juvenile delinquency }\end{array}$ & 2,58 & 2,51 & ,78 & ,67 & 296 & ,587 \\
\hline $\begin{array}{l}\text { Do you think that the police } \\
\text { often exceeds their authority? }\end{array}$ & 2,36 & 2,65 & ,80 & ,71 & 5,760 &, $018^{\star}$ \\
\hline
\end{tabular}

$\mathrm{p}>0,01^{* *}$

$\mathrm{p}>0,05^{\star}$

Table 5 shows the data about the arithmetic means, standard deviations of groups, F-test and importance (P) because of the possible exsistance of differences between groups of manifestant variables. The manifestant variable which describes the efficacity of the police in protection of minorities is important on the level of importance 
$\mathrm{p}>0.01$, while the variables which describe the use and help which citizens have from the police, motivation of police officers, their exceeding of authority and efficacity in crime prevention are important on the level of importance $p>0.05$.

\section{CONCLUSION}

The obtained indicators can confirm the set hypothesis. It can be concluded that there are differences in perception of police procedures by the Roma and local women, in the sense that the Roma women think that the police often exceed their authority, while local women, more often than the Roma ones, talk about some positive characteristics of police procedures and personal characteristics of police officers like the use and help which citizens have from the police, their efficacity in protecting minorities, and their consistency, rapidity and motivation.

While analysing the exceeding of authority by the police, Janofsky (1997) says that in the Unated States of America the thought that police officers discriminate minorities, especially Afro-Americans, is widespread, and this is confirmed in a number of incidents (brutal treatment, corruption and similar incidents). On the other hand, when it comes to women, there is a discordance between a high level of victimisation of Afro-American women, and a low level of proper, adequate approach (Belknap, 1996). Analysing the victimisation of Afro-American women as a minority group in the United States of America, Ogawa (1988) sees differences in procedures of the law system in the widest sense, especially when it comes to extreme violence.

On the basis of the shown results, and taking into account the results of the above mentioned researches (Belknap,1996; Ogawa, 1988; Janofsky, 1997) it can be assumed and concluded that although the Roma women estimate some aspects of the police relatively high, they still dominantly percieve some negative characteristics of police procedures and think that the police exceed their authority. It is evident that such negative marks of police procedures by the Roma women are affected by some other factors, not just by opinions about some characteristics of police officers. It can be a question of negative experiences of the Roma women linked to their ethnic discrimination (Radetić-Paić, 2009). Police officers who are seen by the Roma women as having positive characteristics in some aspects do not reflect those characteristics in their procedures because they express some of their opinions in them, which can be negative toward the Roma as an ethnic minority. What follows is the conclusion that the Roma women from Istria, the Republic of Croatia, expectations concerning public protection from crime are loaded with the experience of their negative ethnic discrimination.

This research represents a step toward the role of female members of the Roma community from objects to subjects of criminal law and social security. The scientific and applicative value of this research's results are the guidelines which it gives for the creation and implementation of measures for the protection of families, women, children and youths belonging to the Roma minority group of the Istrian County, the Republic of Croatia. 


\section{BIBLIOGRAPHY}

1. Belknap, J. (1996). The Invisible Woman: Gender, Crime and Justice. Belmont. California: Wadsworth.

2. Bowling, B. (1999). Violent Racism: Victimisation, Policing, and Social Context. Clarendon Studies in Criminology. Oxford: Oxford University Press.

3. Cajner Mraović, I. \& Mraović, A. (2000). Extremistic violence: Some Basic Questions about the Fenomenology, Aetiology and Prevention of the Phenomenon? Police and Safety, 9, 174-186.

4. Cajner Mraović, I. (2003). Police and protection of vulnerable groups: children, women and minorities. Anthology of the Faculty of Law, University of Rijeka, 24,(2) 871-891.

5. Correia M.E. (2010). Determinants of attitudes toward police of Latino immigrants and non-immigrants. Journal of Criminal Justice, 38, (1) 99-107.

6. Jang, H., Joo H-J., \& Zhao, J.S. (2010). Determinants of public confidence in police: An international perspective. Journal of Criminal Justice, 38, (1) 57-68.

7. Janofsky, M. (1997). Under Siege, Philadelphia's Criminal Justice System Suffers Another Blow. The New York Times. (April 10), 14A.

8. Levin, J. (2002). The Violence of Hate: Confronting Racism, Anti-Semitism, and Other Forms of Bigotry. Allyn \& Bacon.Boston.

9. McKean, J. (1994). Trace, Ethnicity and Criminal Justice. In J.E. Hendricks and B. Byers (Eds.), Multicultural Perspectives in Criminal Justice and Criminology (pp.78-20). Springfield.

10. Miethe, T. D., Stafford, M.C., \& Long, J.S. (1987). Social Differentiation in Criminal Victimization: A Test of Routine Activities/Lifestyle Theories. American Sociological Review, 52, 184-194.

11. O’Brien, E. M. (1989). Black Woman Additionally Victimized by Myths, Stereo-types. Black Issues in Higher Educations. 8-9.

12. Ogawa, B. K. (1988). Couseling Victims of Sexual Assault. International Bulletin of Morita Therapy, 1, (1), 19-25.

13. Ogawa, B. K. (1999). Colour of Justice: Culturally Sensitive Treatment of Minority Crime Victims. Allyn and Bacon. California.

14. Punch, M. (1979). The Secret Social Service. In S. Holdaway (Ed.) The British Police (pp.102-117). London: Arnold.

15. Radetić-Paić, M. (2009). Istrian Roma - Victims of Criminality: different perception of the levels of security by the Roma versus the remaining Istrian population. Doctoral Dissertation. Zagreb: Educational-rehabilitative Faculty of the Zagreb University.

16. Reiner, R. (1994). Policing the Police. In M. Maguire, R. Morgan \& R. Reiner, (Eds.), The Oxford Handbook of Criminology (pp. 705-772). Oxford: Oxford University Press.

17. Ren, L., Cao, L., Lovrich, N., \& Gaffney, M. (2005). Linking confidence in the police with the performance of the police: Community policing can make a difference. Journal of Criminal Justice, 33 (1), 55-66.

18. Rosenbaum, D. (1998). The Changing Role of the Police: Assessing the Current Transition to Community Policing. In J. P. Brodeur (Ed.), How to Recognize Good Policing. 
Problems and Issues. London: SAGE Publications.

19. Schwendinger, J.R., \& Schwendinger, N. (1983). Rape and Inequality. Beverly Hills. California: Sage.

20. Stephens, M. \& Saul B. (1994). Police Force Police Service. Care and Control in Britain. London: Macmillan.

21. Šucur, Z. (2005). Poverty as a Part of the Sociocultural Identity of the Roma. In M.Štambuk (Ed.), How do Croatian Rome Live (pp.271-315). Institute for Social Studies "Ivo Pilar," Zagreb.

22. The Committee on the Constitution, Standing Orders and Political System of the Croatian Parliament (2001). The Constitution. Consolidated text. „Narodne novine, “ no. 41.

23. The Croatian Government (2003). National Programme for the Roma. Zagreb: The Croatian Government.

24. The Croatian Government (2005). The Action Plan of the Decade for the Roma Implementation 2005 - 2015. Zagreb: The Croatian Government.

25. The Institute for Social Sciences Ivo Pilar (1998). The Social and Developmental Position of the Roma in Croatia. Zagreb: The Institute for Social Sciences Ivo Pilar.

26. The National Department for the Protection of Family, Motherhood and the Youth (2002). The Structure of the Roma families and the Conception of Parenthood in them. Zagreb: The National Department for the Protection of Family, Motherhood and the Youth.

27. UN General Assembly (1979). The Convention on the Elimination of All Forms of Discrimination against Women - CEDAW. UN General Assembly

28. Uzelac, S (2004a). Some Ethic Questions on Features of Behavioural Disturbancies of Children and the Youth. In J.Bašić, N. Koller-Trbović \& S. Uzelac (Eds.) Behavioural Disturbancies and Risky Behaviours: Approaches and Conceptual Features. (pp. 73-81). Zagreb: Educational - Rehabilitative Faculty, University of Zagreb.

29. Uzelac, S (2004b). The Needs and Possibilities of a Unique Evidence of Behavioural Disturbancies. In J.Bašić, N. Koller-Trbović \& S. Uzelac (Eds.) Behavioural Disturbancies and Risky Behaviours: Approaches and Conceptual Features. (pp. 141-147). Zagreb: Educational - Rehabilitative Faculty, University of Zagreb.

30. Westley, W. A. (2004). Violence and the Police. In I. Kuvačić (Ed.), Introduction to Sociology (pp. 506-510). Zagreb: Golden Marketing-Tehnička knjiga.

31. Wyatt, G. E. (1992). The Sociocultural Context African American Women's Rape. Journal of Social Issues, 48, 77-91.

32. Zidarić, V. (1994). Topical Questions about the Roma Education in Countries Members of the European Union. In N. Hrvatić (Ed.), Education and training of the Roma Children in Croatia: collected papers - Macinec (pp 76-81). The Union of the Roma Associations in Croatia.

33. Zoon, I. (2002). Report on obstacles facing the Roma minority of Croatia in accessing different categories of rights and namely citizenship, housing, health and social assistance. Roma under the Stability Pact. Concil of Europe European Commission. 